\title{
Effect of Prolonged Prazosin Treatment on Hemodynamic and Biochemical Changes in the Dog Heart Due to Chronic Pressure Overload
}

\author{
K. Prasad, M.D., Ph.D., C.L. O’Neil, M.Sc., and \\ B. Bharadwaj, M.D.
}

SUmMary

A decrease in cardiac function and intracellular calcium, and an increase in cardiac sarcolemmal ATPase have been reported in experimentally induced aortic stenosis of 6 to 9 months duration. Prazosin has been used in the treatment of heart failure due to mechanical ventricular overload. It is, however, not known whether prazosin treatment gives only hemodynamic benefit with accompanying subjective improvement or if it also improves the condition of the myocardium in terms of contractility and biochemical changes. The present investigation deals with the effects of 3 months of prazosin treatment on cardiac function, electrolytes, and ATPase in dogs with aortic stenosis of 3 months duration. Although there were no significant changes in most of the left and right ventricular hemodynamic parameters, the left ventricular enddiastolic pressure increased significantly after 3 months of aortic stenosis. Prazosin prevented further deterioration of cardiac function. All the dogs developed left ventricular hypertrophy and all chest X-rays showed cardiomegaly. Concomitant with these changes, there was a tendency towards a decrease in total tissue $\mathrm{Ca}^{++}$and intracellular $\mathrm{Ca}^{++}$and $\mathrm{K}^{+}$and a tendency towards an increase in sarcolemmal $\mathrm{Na}^{+}-\mathrm{K}^{+}-\mathrm{ATPase}$. Prazosin treatment, although it markedly reduced left ventricular end-diastolic pressure, did not reduce the cardiomegaly. There were no significant changes in any of the other hemodynamic parameters. Prazosin treatment decreased sarcolemmal ATPase and tended to increase intracellular $\mathrm{Ca}^{++}$. It appears therefore that prazosin not only tends to bring the cardiac function towards control values but also tends to correct the ATPase and intracellular $\mathrm{Ca}{ }^{++}$levels of the failing heart.

From the Departments of Physiology and Cardiovascular Surgery, College of Medicine, University of Saskatchewan, Saskatoon, Canada.

Address for reprint: K. Prasad, M.D., Department of Physiology, College of Medicine, University of Saskatchewan, Saskatoon, Sask., Canada S7N OWO.

Received for publication February 15, 1983.

Manuscript revised June $8,1983$. 


\section{Additional Indexing Words:}

Hemodynamics Chronic pressure overloaded heart Chronic prazosin treatment $\mathrm{Na}^{+}-\mathrm{K}^{+}$-ATPase Sarcolemma Cardiac electrolytes Extracellular space

7 HE role of calcium in excitation-contraction coupling is well known. 1 However, the immediate source of the calcium that couples excitation is controversial. Recent studies have shown that the major source of coupling $\mathrm{Ca}^{++}$in cardiac muscles is external via an electroneutral carrier, while a small amount is electrogenic, ${ }^{1,2)}$ Based on available experimental data, Prasad ${ }^{11}$ suggested a model of ion flux through the sarcolemma. According to this model, an increase in sarcolemmal $\mathrm{Na}^{+}-\mathrm{K}^{+}-\mathrm{ATPase}$ would decrease the influx of $\mathrm{Ca}^{++}$and hence contractility. It has been shown that there is an increase in sarcolemmal $\mathrm{Na}^{+}-\mathrm{K}^{+}$-ATPase associated with a decrease in myocardial function in chronic heart failure induced by mitral insufficiency ${ }^{31,4)}$ and aortic stenosis. ${ }^{5)}$ There was also a decrease in intracellular $\mathrm{Na}^{+}$and $\mathrm{Ca}^{++}$, and an increase in $\mathrm{K}^{+}$in these conditions. ${ }^{5,6)}$ The changes in electrolytes and $\mathrm{Na}^{+-}$ $\mathrm{K}^{+}$-ATPase were related to the severity and duration of heart failure. These studies indicate that the defect might lie in the delivery of calcium to the contractile element in the failing heart due to pressure or volume overload.

The physiological approach to the medical treatment of congestive heart failure is based upon the adjustment of determinants of cardiac performance i.e. preload, afterload and contractility. Conventionally, medical treatment consists of positive inotropic agents, the cardiac glycosides. Recently, attention has been focused on the use of agents that reduce preload and afterload in the treatment of congestive heart failure. ${ }^{\text {i)-11) }}$ Prazosin, which reduces both preload and afterload, has been used clinically in the treatment of heart failure due to mechanical ventricular overload and acute myocardial infarction..$^{7,10)-15)}$ It is, however, not known whether these drugs give only hemodynamic benefit with accompanying subjective improvement or also improve the condition of the myocardium in terms of electromechanical and biochemical changes.

It was therefore decided to study in dogs whether prazosin treatment would reverse the hemodynamic and biochemical (myocardial electrolyte and ATPase) changes of the failing heart caused by pressure overload (aortic stenosis).

\section{MetHods}

Hemodynamic measurements: The experiments were carried out on mongrel 
dogs of either sex weighing between 15 and $27 \mathrm{Kg}$. The dogs were divided into 3 groups each consisting of 5 dogs. $A=$ control; $B=$ dogs with 3 months of aortic stenosis; $\mathrm{C}=$ dogs with 3 months of prazosin treatment after 3 months of aortic stenosis. Group D with 6 months of aortic stenosis without prazosin treatment was not included in this study for comparison with prazosin treatment because this study has already been reported by the present investigators. ${ }^{5)}$ Also adding an additional similar group would have added unnecessary expense to the present project. The data of this 6 months of aortic stenosis have been used for comparison in the discussion section. Hemodynamic data comprised of pooled data from 35 control dogs, 15 dogs with 3 months of aortic stenosis, and 5 dogs with 3 months of prazosin treatment after 3 months of aortic stenosis. Fifteen dogs for hemodynamic study in Group B comprised of pooled data from following subgroups: 5 stenotic dogs sacrificed at 3 months; 5 stenotic dogs treated with prazosin; and 5 stenotic dogs treated with digoxin in another study. For biochemical parameters each group consists of 5 dogs. No prazosin was administered during the 72 hours before hemodynamics were measured and the dogs were sacrificed. This time was selected so that the drug would not interfere with the chemical and hemodynamic measurements. The aim of the treatment was to determine if the chronic treatment was of value in improving the condition of the myocardium in terms of myocardial function and biochemical parameters. The aim was not to see the changes in hemodynamics in the presence of drugs.

The dogs were anaesthetized with pentothal sodium ( $25 \mathrm{mg} / \mathrm{Kg}$, i.v.). A satisfactory plane of anaesthesia was maintained with halothane via a closed cuff endotracheal tube. The femoral vein and artery were exposed for hemodynamic measurements. Right and left ventricular, aortic and right atrial pressures were recorded with an Ailtech microdot pressure transducer and a Beckman R 411 dynograph recorder. A 7 French guage Cournand (Cordis GF) catheter was positioned at the aortic arch via the femoral artery to record aortic pressure. The same catheter was later advanced into the left ventricle to record left ventricular pressure. A Swan-Ganz catheter ( 7 French guage) was positioned in the right atrium via the femoral vein to record right atrial pressure and through which cardiogreen dye was injected for cardiac output determination. The same catheter was used to record right ventricular pressure. The first derivatives of left and right ventricular pressures were recorded with a differentiating device coupled to ventricular pressure gauges at a frequency response of $100 \mathrm{~Hz}$.

Integrated isovolumetric pressure (IIP) was measured by the method of Siegel et al. ${ }^{16)}$ The ratio of $\mathrm{dP} / \mathrm{dt} / \mathrm{IIP}$ was used as one of the measures of myocardial contractility because it is not affected by preload or by small 
changes in heart rate. ${ }^{16), 17)}$ The ratio of $\mathrm{dP} / \mathrm{dt}$ is affected by preload, afterload, and heart rate in addition to contractility. The electrocardiogram from leads I, II, III, ${ }_{\mathrm{a}} \mathrm{V}_{\mathrm{R}},{ }_{\mathrm{a}} \mathrm{V}_{\mathrm{L}}$, and ${ }_{\mathrm{a}} \mathrm{V}_{\mathrm{F}}$ was recorded.

The cardiac output was determined in duplicate by the usual indicator dilution technique. Left ventricular work index, total systemic vascular resistance, and cardiac index were calculated by the method described earlier by Prasad et al. ${ }^{5}$

Chest X-rays were also taken for a rough estimate of the size of the heart. The hemodynamic measurements, 6 lead electrocardiograms and chest X-rays were taken before aortic banding was performed, after 3 months of aortic banding before institution of prazosin treatment and after 3 months of prazosin treatment before the dogs were sacrificed.

Surgical procedure for aortic banding: The methods of aortic banding were the same as described earlier by Prasad et al. ${ }^{5}$. The heart was exposed by opening the chest through the fourth intercostal space under halothane anaesthesia. The pericardium was cut and the heart and ascending aorta were exposed. A nonelastic dacron band was tied around the ascending aorta such that the systolic pressure gradient between the left ventricle and the aorta beyond the band was 20 to $30 \mathrm{mmHg}$. The chest was closed and the dog allowed to develop left ventricular failure for a specified time of 3 and 6 months. Left ventricular failure was considered present when the following signs appeared: decreases in the index of myocardial contractility $((\mathrm{dP} / \mathrm{dt}) / \mathrm{IIP}$ of left ventricular pressure), cardiac index, and left ventricular work index; an increase in left ventricular end-diastolic pressure associated with cardiac enlargement.

Calculation of extracellular space and intracellular electrolytes: The method described by Prasad et al ${ }^{51}$ was used to measure extracellular space. After hemodynamic measurements were made, the chest was opened through the left fifth intercostal space to expose the heart. Inulin- $\mathrm{H}^{3}$ ( $\mathrm{g}$ ) (New England Nuclear) in a dose of $100 \mu \mathrm{Gi}$ was injected intravenously and the tracer was allowed to equilibrate for $15 \mathrm{~min}$. This period was chosen because in our earlier studies, 5 " equilibrium was reached within $10 \mathrm{~min}$. After fixed equilibration, $1 \mathrm{ml}$ of blood was withdrawn with a heparinized syringe from the coronary sinus and the heart was quickly excised. Samples of tissue from the left and right ventricles were removed immediately for the determination of insulin space and concentrations of electrolytes and ATPase. To determine insulin space, duplicate samples of ventricular tissue $(0.1 \mathrm{Gm})$ and of coronary sinus plasma $(0.1 \mathrm{ml})$ were transferred to scintillation counting vials containing $0.2 \mathrm{ml}$ of perchloric acid and $0.3 \mathrm{ml}$ of hydrogen peroxide. Both plasma and tissue samples were allowed to digest in the mixture for 24 hours at $38^{\circ} \mathrm{C}$, 
after which they were refrigerated for 2 hours. Ten $\mathrm{ml}$ of Biofluor (R) (New England Nuclear) was then added to each sample which was then refrigerated for a further period of 4 hours. Radioactivity was counted in each sample by a liquid scintillation counter using external standards and the channel ratio method. The radioactivity counts in samples were corrected for quenching using a prepared standard curve. The extracellular space was computed from the radioactivity counts for the muscle and plasma samples. The ratios of the spccific activities in the muscle and plasma were calculated. This ratio is equal to the ratio of the extracellular space to the total muscle volume (assuming the density of both muscle and water to be the same). Thus ECS= Am/Ap, where ECS is the extracellular space and Am and Ap are the muscle and plasma radioactivity counts $\left(\mathrm{Cpm} . \mathrm{Cm}^{-3}\right)$ respectively.

The extracellular ion concentrations were taken to be the same as those in the plasma. The intracellular concentration of ion $\mathrm{X}$ is given by:

$$
\mathrm{X}_{\mathrm{i}}=\frac{\mathrm{Xm}-(\mathrm{ECS} \times \mathrm{Xp})}{1-\mathrm{ECS}}
$$

where subscripts $\mathrm{i}, \mathrm{m}$, and $\mathrm{p}$ refer to intracellular, muscle and plasma concentrations of ion $\mathrm{X}$.

Measurement of tissue and plasma electrolytes: Electrolytes were measured by the method described earlier by Prasad et al.5) Briefly, for cation $\left(\mathrm{Na}^{+}, \mathrm{K}^{+}\right.$, and $\mathrm{Ca}^{++}$) measurements, $1 \mathrm{Gm}$ samples from the left and right ventricles were each blotted dry and transferred immediately to a test tube containing a mixture of $0.5 \mathrm{ml}$ of $70 \%$ perchloric acid and $0.5 \mathrm{ml}$ of concentrated nitric acid. The tissue was allowed to digest in the mixture overnight at $40^{\circ} \mathrm{C}$ in a sand bath. Lanthanum chloride $(0.5 \%)$ was then added in the test tube containing digested tissue to make the final volume of $10 \mathrm{ml}$. A portion of this solution was used for the measurement of cations. One $\mathrm{ml}$ of plasma sample was diluted to $25 \mathrm{ml}$ with $0.5 \%$ lanthanum chloride. A portion of this solution was then diluted with distilled water for the measurement of plasma cation.

Calcium was measured using a Perkin-Elmer 303 atomic absorption spectrophotometer. ${ }^{18)}$ Sodium and potassium were measured using a flame photometer.

Measurement of sarcolemmal $\mathrm{Na}^{+}-K^{+}-A$ TPase: The dogs were sacrificed at the end of the protocol after hemodynamic measurements were made. Samples from the right and left ventricles were taken and quickly frozen for estimation of sarcolemmal $\mathrm{Mg}^{2+}$-dependent, $\mathrm{Na}^{+}-\mathrm{K}+$ ATPase activity. The methods of Kidwai et al $^{19)}$ were used to isolate the sarcolemmal fraction and to estimate $\mathrm{Na}^{+}-\mathrm{K}^{+}$-ATPase. Protein content was determined by the methods of Lowry et al. ${ }^{20}$ These methods have been described in detail in earlier 
Table I. Hemodynamics in Normal and Aortic

\begin{tabular}{|c|c|c|c|c|c|c|}
\hline & \multicolumn{4}{|c|}{ Left Ventricle } & \multicolumn{2}{|c|}{ Right Ventricle } \\
\hline & $\begin{array}{c}\mathrm{SP} \\
(\mathrm{mmHg})\end{array}$ & $\begin{array}{c}\mathrm{dP} / \mathrm{dt} \\
(\mathrm{mmHg} / \mathrm{sec})\end{array}$ & $\frac{\mathrm{dP} / \mathrm{dt}}{\underset{\left(\sec ^{-2}\right)}{ }}$ & $\begin{array}{c}\mathrm{LVWI} \\
\left(\mathrm{Kg}-\mathrm{m} / \mathrm{min} / \mathrm{m}^{2}\right)\end{array}$ & $\underset{(\mathrm{mmHg})}{\mathrm{SP}}$ & $\underset{(\mathrm{mec})}{\mathrm{dP} / \mathrm{dt}}$ \\
\hline Normal $(n=35)$ & $\begin{array}{l}174.6 \\
\pm 4.46\end{array}$ & $\begin{array}{c}1913 \\
\pm 139.5\end{array}$ & $\begin{array}{l}158.2 \\
\pm 16.83\end{array}$ & $\begin{array}{r}9.07 \\
\pm 0.57\end{array}$ & $\begin{array}{r}40.46 \\
\pm 1.71\end{array}$ & $\begin{array}{l}39.1 \\
\pm 19.5\end{array}$ \\
\hline Stenotic $(n=15)$ & $\begin{array}{l}192 \\
\pm 10.3\end{array}$ & $\begin{array}{c}2098 \\
\pm 218.6\end{array}$ & $\begin{array}{r}181.4 \\
\pm 35.8\end{array}$ & $\begin{array}{r}9.47 \\
\pm 1.27\end{array}$ & $\begin{array}{c}42.5 \\
\pm 2.76\end{array}$ & $\begin{array}{l}458 \\
\pm 61.7\end{array}$ \\
\hline Sten/Praz $(n=5)$ & $\begin{array}{r}182 \\
\pm 18.88\end{array}$ & $\begin{array}{c}1942 \\
\pm 348.4\end{array}$ & $\begin{array}{r}126.5 \\
\pm 23.3\end{array}$ & $\begin{aligned} & 5.69 \\
\pm & 1.57 * * *\end{aligned}$ & $\begin{array}{l}33 \\
\pm 1.35+t\end{array}$ & $\begin{array}{r}312.2 \\
\pm 27.8\end{array}$ \\
\hline
\end{tabular}

The results are expressed as mean \pm S.E. Stenotic $=$ aortic stenosis; Sten/Praz $=$ aortic stenoticprazosin treated; $\mathrm{SP}=$ systolic pressure; $\mathrm{LVWI}=$ left ventricular work index; $\mathrm{HR}=$ heart rate; $\mathrm{RAP}=$ right atrial pressure ; $\mathrm{S}=$ systolic ; $\mathrm{D}=$ diastolic $; \mathrm{M}=$ mean ; $\mathrm{CO}=$ cardiac output ; $\mathrm{SV}=$ stroke volume; $\mathrm{n}=$ number of dogs.

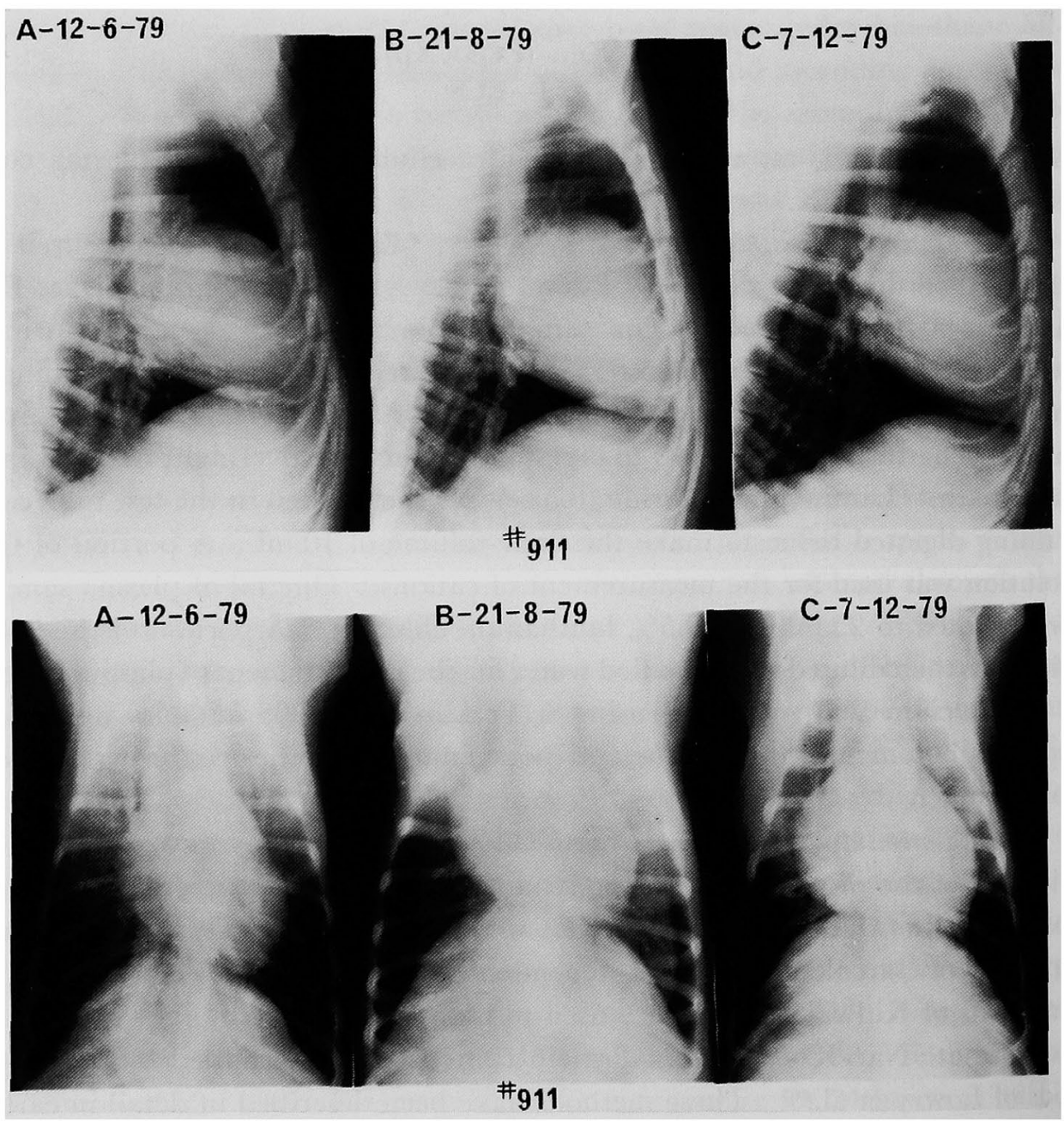


Stenotic Dogs with and without Prazosin Treatment

\begin{tabular}{|c|c|c|c|c|c|c|c|}
\hline \multirow{2}{*}{$\frac{\mathrm{dP} / \mathrm{d} t}{\operatorname{IIP}}$} & \multicolumn{3}{|c|}{ Aortic Blood Pressure (mmHg) } & \multirow{2}{*}{$\begin{array}{c}\text { HR } \\
\text { (beats/min) }\end{array}$} & \multirow{2}{*}{$\underset{(\mathrm{mmHg})}{\mathrm{RAP}}$} & \multirow{2}{*}{$\begin{array}{c}\mathrm{CO} \\
(\mathrm{L} / \mathrm{min})\end{array}$} & \multirow{2}{*}{$\begin{array}{c}\mathrm{SV} \\
(\mathrm{mls})\end{array}$} \\
\hline & $\mathrm{S}$ & $\mathrm{D}$ & M & & & & \\
\hline $\begin{array}{c}155.1 \\
\pm 10.45\end{array}$ & $\begin{array}{l}162.4 \\
\pm 4.95\end{array}$ & $\begin{array}{l}121.9 \\
\pm 4.50\end{array}$ & $\begin{array}{l}137.7 \\
\pm 4.34\end{array}$ & $\begin{array}{l}129.6 \\
\pm 4.64\end{array}$ & $\begin{array}{r}3.88 \\
\pm 0.33\end{array}$ & $\begin{array}{r}3.63 \\
\pm 0.20\end{array}$ & $\begin{array}{c}27.7 \\
\pm 1.07\end{array}$ \\
\hline $\begin{array}{r}140.4 \\
\pm 11.8\end{array}$ & $\begin{array}{l}164 \\
\pm 9.41\end{array}$ & $\begin{array}{l}108.7 \\
\pm 8.06\end{array}$ & $\begin{array}{l}126.6 \\
\pm 8.79\end{array}$ & $\begin{array}{l}122 \\
\pm 7.39\end{array}$ & 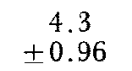 & $\begin{array}{r}2.85 \\
+0.22\end{array}$ & $\begin{array}{c}25.4 \\
\pm 1.66\end{array}$ \\
\hline $\begin{array}{r}157.7 \\
\pm 32.2\end{array}$ & $\begin{array}{r}157 \\
\pm 19.0\end{array}$ & $\begin{array}{l}101 \\
\pm 8.88\end{array}$ & $\begin{array}{l}119 \\
\pm 5.39\end{array}$ & $\begin{array}{c}96 \\
\pm 4.2\end{array}$ & $\begin{array}{c}3.2 \\
\pm 0.92\end{array}$ & $\begin{aligned} & 2.14 \\
\pm & 0.23^{* * *}\end{aligned}$ & $\begin{array}{c}22.4 \\
\pm 2.30\end{array}$ \\
\hline
\end{tabular}

* $\mathrm{p}<0.05$; a comparison between the normal control dogs and the aortic stenotic untreated dogs. *** $\mathrm{p}<0.05$; normal control dogs vs. aortic stenotic-prazosin treated dogs. $\dagger \dagger \mathrm{p}<0.05$; aortic stenotic dogs vs. aortic stenotic-prazosin treated dogs.

papers by Prasad ${ }^{21)}$ and Khatter and Prasad. ${ }^{22)} \quad \mathrm{Na}^{+}-\mathrm{K}^{+}-$ATPase activity of the failing and normal heart was determined under various conditions $\left(\mathrm{Na}^{+}\right.$, $\left.\mathrm{K}^{+}, \mathrm{pH}, \mathrm{ATP}\right)$ to establish optimal assay conditions. The optimal conditions for $\mathrm{Na}^{+}-\mathrm{K}^{+}$-ATPase activity in both failing and normal hearts have already been reported in a previous paper by Prasad et al.5) The ATPase activity in the presence of $10^{-3} \mathrm{M}$ per liter ouabain in the assay medium was subtacted from that in the absence of ouabain in the assay medium to obtain the $\mathrm{Mg}^{+{ }_{-}}$ dependent, $\mathrm{Na}^{+}-\mathrm{K}^{+}$stimulated ouabain sensitive portion of ATPase activity.

Extracellular space, intracellular electrolytes, $\mathrm{Mg}^{++}$-dependent, $\mathrm{Na}^{+-\mathrm{K}^{+}}$ stimulated sarcolemmal adenosine-triphosphatase were analyzed at the end of the study.

\section{Results}

A. Chest X-ray: Chest X-ray showed that the heart was enlarged in all the aorta banded dogs. A typical radiograph is shown in Fig. 1. Prazosin treatment did not affect the enlargement seen after 3 months of aortic stenosis.

B. Hemodynamics: There were no significant changes in heart rate, blood pressure, left ventricular systolic pressure, right ventricular systolic pressure, left and right ventricular $\mathrm{dP} / \mathrm{dt},(\mathrm{dP} / \mathrm{dt}) / \mathrm{IIP}$ of left and right ventricle,

Fig. 1. Lateral and dorsoventral chest X-ray of normal dogs, dogs following 3 months of aortic banding, and prazosin treated dogs (No. 911). Upper=lateral thoracic radiographs; Lower=dorsoventral thoracic radiographs. $\mathrm{A}=$ control $\operatorname{dog} ; \mathrm{B}=\mathrm{dog}$ with aortic stenosis of 3 months duration; $\mathrm{C}=$ stenotic dog treated with prazosin for 3 months. Note the increased heart size, rounding of the ventricle, and increased sternal contact after 3 months of aortic stenosis. Note also that prazosin treatment did not affect the heart size of stenotic dogs. 
cardiac output, and stroke volume after 3 months of aortic stenosis, although there was a tendency towards an increase in the left ventricular systolic pressure and right atrial pressure, and a decrease in the cardiac output and stroke volume (Table I). Prazosin treatment for 3 months in these stenotic dogs significantly reduced the left ventricular work index, right ventricular systolic pressure, and cardiac output. Other parameters did not change sig-

\section{SIGNIFICANCE TABLES}

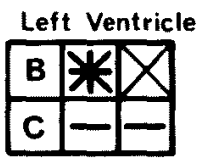

A B
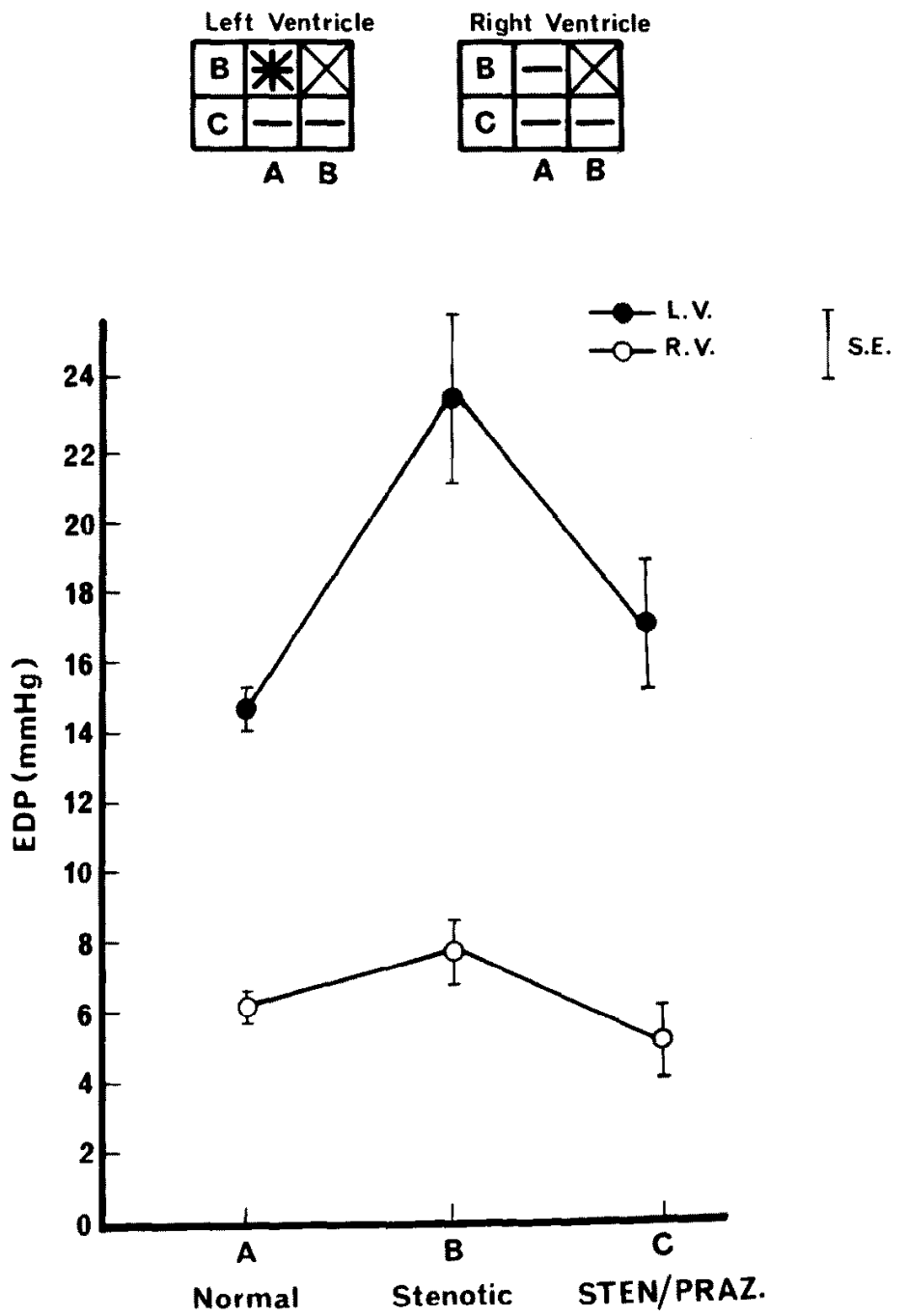

Fig. 2. The effect of aortic stenosis with and without prazosin treatment on left and right yentricular end-diastolic pressures. $A=$ normal; $B=3$ months of aortic stenosis; $C=3$ months of prazosin treatment in dogs with aortic stenosis. Significance tables for left and right ventricles are at the top. The values for $A$ have been compared with $B$ and $C$ and those of $B$ with $C$. $(*)=$ significant at 0.05 level; $(-)=$ not significant. 
nificantly when compared to the values for control or for untreated stenotic dogs.

The changes in left and right ventricular end-diastolic pressures are summarized in Fig. 2. Left ventricular end-diastolic pressure increased significantly after 3 months of aortic stenosis. The dogs treated with prazosin for 3 months after 3 months of aortic stenosis had left ventricular end-diastolic pressures similar to control but significantly lower than thosc following 3 months of aortic stenosis. There were no significant changes in the right ventricular end-diastolic pressures in any group.

Fig. 3 shows the changes in the cardiac index with various interventions.
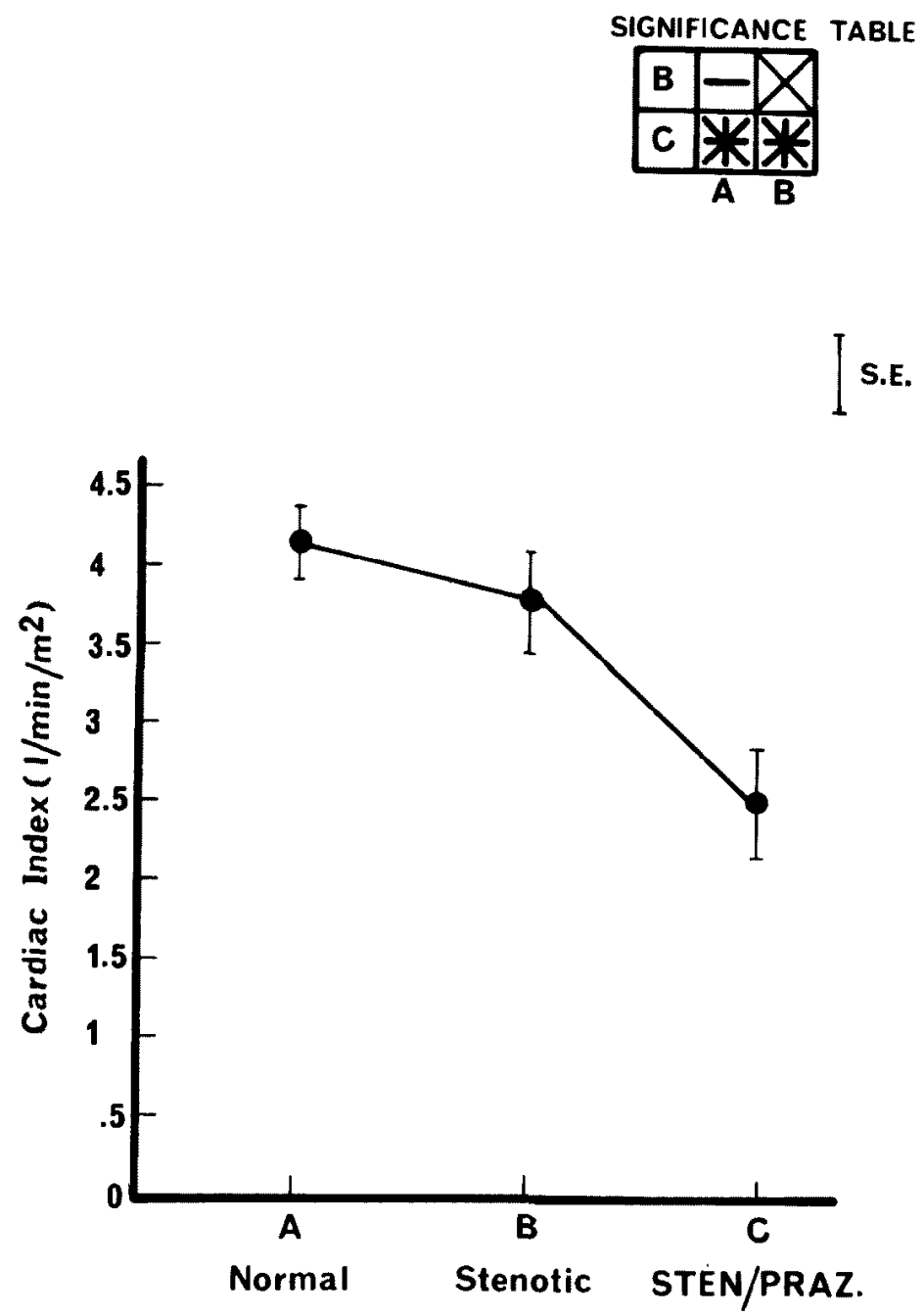

Fig. 3. The effect of aortic stenosis with and without prazosin treatment on the cardiac index. The other abbreviations as in Fig. 2. 

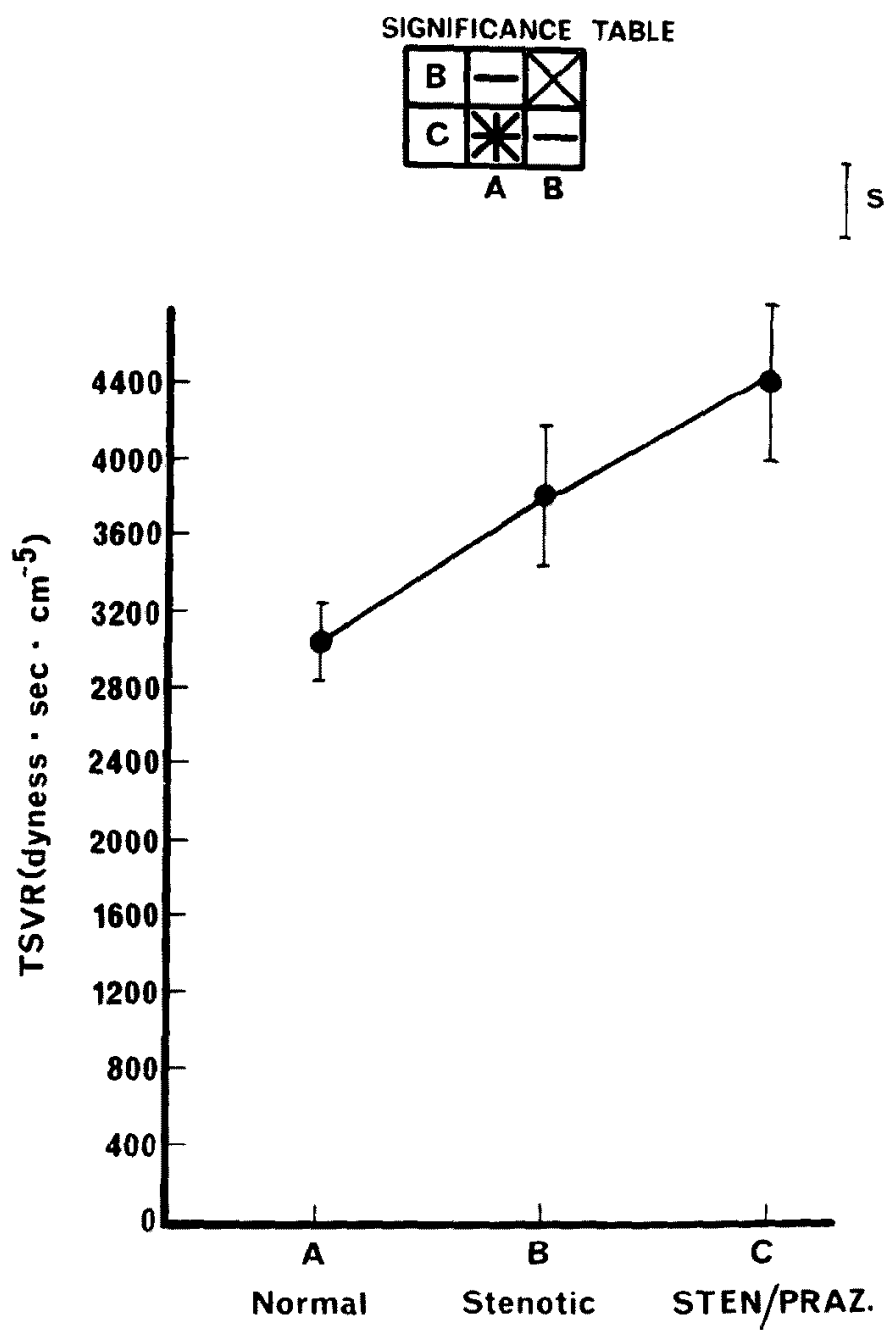

Fig. 4. The effect of aortic stenosis with and without prazosin treatment on total systemic vascular resistance. The other abbreviations as in Fig. 2.

Cardiac index did not change after 3 months of aortic stenosis. With prazosin treatment the cardiac index decreased significantly. Although prazosin was ineffective in increasing the cardiac output and cardiac index in aortic stenotic dogs, the stroke volume following prazosin treatment was not significantly different from the values following 3 months of aortic stenosis (Table I).

The total systemic vascular resistance progressively increased but was not significantly greater than control after 3 months of aortic stenosis (Fig. 4). Prazosin treatment could not prevent further rise in systemic vascular resistance which became significantly higher than control. Autopsies were performed on all dogs with aortic stenosis whether or not they had been treated. 
Left ventricular hypertrophy of varying degree was noted in all dogs.

C. Plasma electrolytes and extracellular space: The results are summarized in Table II. Plasma sodium decreased and plasma potassium increased after 3 months of aortic stenosis. Prazosin treatment did not affect either of these values observed after 3 months of aortic stenosis. There was no significant changes in plasma calcium with any of these interventions.

The values for extracellular space were similar in both ventricles regardless of intervention.

D. Total tissue electrolytes: The results are summarized in Table III. Total tissue $\mathrm{Ca}^{++}$decreased significantly in the left ventricle after 3 months of aortic stenosis. Prazosin treatment increased the tissue $\mathrm{Ca}^{++}$to control values in the stenotic dogs. Right ventricular tissue $\mathrm{Ca}^{++}$did not change. There was a tendency for the tissue sodium to rise in the stenotic dogs but the increase was not significant. Prazosin treatment increased tissue $\mathrm{Na}^{+}$in

Table II. Plasma Electrolytes and Cardiac Extracellular Space in Normal and Aortic Stenotic Dogs with and without Prazosin Treatment

\begin{tabular}{|c|c|c|c|c|c|}
\hline \multirow{2}{*}{ Group } & \multicolumn{3}{|c|}{ Plasma Electrolytes (mEq/L) } & \multicolumn{2}{|c|}{$\begin{array}{l}\text { Extracellular Space } \\
\text { (fraction of unit mass) }\end{array}$} \\
\hline & $\mathrm{Na}^{+}$ & $\mathrm{K}^{+}$ & $\mathrm{Ca}^{++}$ & $\mathrm{LV}$ & RV \\
\hline Normals $(n=5)$ & $146.7 \pm 0.97$ & $4.45 \pm 0.25$ & $4.17 \pm 0.16$ & $0.342 \pm 0.022$ & $0.345 \pm 0.024$ \\
\hline Stenotic $(n=5)$ & $140.9 \pm 1.25 *$ & $5.78 \pm 0.11^{*}$ & $3.96 \pm 0.11$ & $0.415 \pm 0.082$ & $0.421 \pm 0.100$ \\
\hline Sten/Praz $(n=5)$ & $140.5 \pm 0.87 * * *$ & $5.74 \pm 0.30 * * *$ & $4.53 \pm 0.44$ & $0.360 \pm 0.044$ & $0.378 \pm 0.044$ \\
\hline
\end{tabular}

The results are expressed as mean \pm S.E. $n=$ number of experiments; $\quad$ Stenotic=aortic stenosis; $\mathrm{LV}=$ left ventricle; $\mathrm{RV}=$ right ventricle; Sten $/ \operatorname{Praz}=$ aortic stenotic-prazosin treated.

${ }^{*} \mathrm{p}<0.05$; normal control dogs vs. aortic stenotic, untreated dogs. $* * * \mathrm{p}<0.05$; normal control dogs vs. aortic stenotic-prazosin treated dogs.

Table III. Tissue Electrolytes $(\mathrm{mEq} / \mathrm{L})$ in Normal and Aortic Stenotic Dogs with and without Prazosin Treatment

\begin{tabular}{c|ccc|ccr}
\hline \multirow{2}{*}{ Group } & \multicolumn{3}{|c|}{ Left Ventricle } & \multicolumn{3}{c}{ Right Ventricle } \\
\cline { 2 - 7 } & $\mathrm{Na}$ & $\mathrm{K}+$ & $\mathrm{Ca}+$ & $\mathrm{Na}^{+}$ & $\mathrm{K}^{+}$ & $\mathrm{Ca}^{++}$ \\
\hline \multirow{2}{*}{ Normal $(\mathrm{n}=5)$} & 45.6 & 73.5 & 2.98 & 44.7 & 76.4 & 2.63 \\
& \pm 2.67 & \pm 2.84 & \pm 0.29 & \pm 2.08 & \pm 3.43 & \pm 0.09 \\
Stenotic $(\mathrm{n}=5)$ & 52.2 & 72.1 & 2.22 & 54.6 & 70.8 & 2.08 \\
& \pm 2.51 & \pm 2.67 & $\pm 0.21 *$ & \pm 3.34 & \pm 3.20 & \pm 0.21 \\
Sten/Praz $(\mathrm{n}=5)$ & 58.7 & 64.3 & 2.80 & 59.7 & 64.5 & 2.46 \\
& $\pm 2.27 * *$ & \pm 4.12 & \pm 0.219 & $\pm 2.31 * *$ & \pm 4.75 & \pm 0.169
\end{tabular}

The results are expressed as mean \pm S.E. Stenotic =aortic stenosis; Sten/Praz=aortic stenoticprazosin treated; $\mathrm{n}=$ number of experiments.

* $\mathrm{p}<0.05$; a comparison between the normal control dogs and the aortic stenotic untreated dogs. *** $\mathrm{p}<0.05$; normal control dogs vs. aortic stenotic-prazosin treated dogs. 
both the left and right ventricles. There was no change in tissue potassium in either the left or right ventricle with any of the interventions.

E. Intracellular calcium and potassium: The results are summarized in Table IV. There was a tendency for a decrease in intracellular $\mathrm{Ca}^{++}$but the decrease was not significant after 3 months of aortic stenosis. Prazosin treatment increased the intracellular $\mathrm{Ca}^{++}$of the left ventricle in the stenotic dogs. Left ventricular intracellular potassium decreased significantly in the stenotic dogs whereas that of the right ventricle remained unchanged. Prazosin treatment did not change intracellular potassium.

F. Adenosine triphosphatase: The results are summarized in Table V. In both ventricles $\mathrm{Mg}^{++}$-ATPase had a tendency to rise after 3 months of aortic stenosis but the rise was not significant. Prazosin treatment decreased $\mathbf{M g}^{++}$. ATPase in both ventricles.

Right and left ventricular sarcolemmal $\mathrm{Na}^{+}-\mathrm{K}+$-ATPase did not change after 3 months of aortic stenosis. Prazosin significantly decreased $\mathrm{Na}^{+}-\mathrm{K}^{+}$ ATPase in the stenotic dogs.

Table IV. Intracellular Electrolytes (mEq/L) in Normal and Aortic Stenotic Dogs with and without Prazosin Treatment

\begin{tabular}{l|cc|cc}
\hline \multirow{2}{*}{ Group } & \multicolumn{2}{|c|}{ Left Ventricle } & \multicolumn{2}{c}{ Right Ventricle } \\
\cline { 2 - 4 } & \multicolumn{2}{|c|}{$\mathrm{K}^{+}$} & $\mathrm{Ca}^{++}$ & \multicolumn{2}{c}{$\mathrm{K}^{+}$} & $\mathrm{Ca}^{++}$ \\
\hline Normal $(\mathrm{n}=5)$ & $109.2 \pm 5.58$ & $2.29 \pm 0.44$ & $116.0 \pm 4.55$ & $2.03 \pm 0.34$ \\
Stenotic $(\mathrm{n}=5)$ & $99.9 \pm 7.34 *$ & $1.37 \pm 0.49$ & $99.2 \pm 4.34$ & $1.34 \pm 0.41$ \\
Sten/Praz $(\mathrm{n}=5)$ & $86.8 \pm 8.33^{*}$ & $1.93 \pm 0.223$ & $95.0 \pm 6.08$ & $1.27 \pm 0.204$
\end{tabular}

The results are expressed as mean \pm S.E. Stenotic $=$ aortic stenosis; Sten/Praz=aortic stenoticprazosin treated; $n=$ number of experiments.

* $p<0.05$; normal control dogs vs. aortic stenotic untreatcd or prazosin treated dogs.

Table V. Cardiac Sarcolemmal ATPase in Normal and Aortic Stenotic Dogs with and without Prazosin Treatment

\begin{tabular}{|c|c|c|c|c|}
\hline \multirow{2}{*}{ Group } & \multicolumn{2}{|c|}{$\begin{array}{c}\mathrm{Na}^{+}-\mathrm{K}^{+}-\mathrm{ATPase} \\
\left(\mu \mathrm{MP} \mathrm{P}_{\left.\mathrm{i} \cdot \mathrm{Ing}^{-1} \text { protein } \cdot \mathrm{h}^{-1}\right)}\right.\end{array}$} & \multicolumn{2}{|c|}{$\begin{array}{l}\mathrm{Mg}^{2+} \text {-stimulated ATPase } \\
\left(\mu \mathrm{Mi} \cdot \mathrm{mg}^{-1} \text { protein } \cdot \mathrm{h}^{-1}\right)\end{array}$} \\
\hline & LV & RV & LV & RV \\
\hline Normal $(n=5)$ & $5.90 \pm 0.75$ & $6.76 \pm 1.66$ & $17.58 \pm 1.78$ & $17.50 \pm 2.97$ \\
\hline Stenotic $(n=5)$ & $6.02 \pm 0.57$ & $7.54 \pm 1.61$ & $29.1 \pm 6.16$ & $33.4 \pm 8.34$ \\
\hline Sten/Praz $(n=5)$ & $2.97 \pm 0.50_{++*}^{* * * *}$ & $3.24 \pm 0.35_{t+*}^{* * *}$ & $6.92 \pm 1.54_{+t}^{* * *}$ & $12.89 \pm 3.25_{++}^{* * *}$ \\
\hline
\end{tabular}

The results are expressed as mean \pm S.E. $n=$ number of experiments; Stenotic=aortic stenosis; Sten/Praz = aortic stenotic-prazosin treated.

${ }^{+} \mathrm{p}<0.05$; aortic stenotic dogs vs. aortic stenotic-prazosin treated dogs. $* * * \mathrm{p}<0.05$; normal control dogs vs. aortic stenotic-prazosin treated dogs. 


\section{Discussion}

The dose of prazosin $(0.2 \mathrm{mg} / \mathrm{Kg}$ orally twice daily) was selected for this study based on previous reported doses in dogs. Prazosin in a dose of $0.1 \mathrm{mg} /$ $\mathrm{Kg}^{23)}$ and $0.5 \mathrm{mg} / \mathrm{Kg}^{24)}$ twice daily orally has been reported to produce a significant fall in blood pressure. In humans, prazosin has been used orally in a dose of 3 to $28 \mathrm{mg}$ daily in divided doses. ${ }^{10)-14}$

Although there were no significant changes in most of the ventricular hemodynamic parameters, the left ventricular end-diastolic pressure increased significantly after 3 months of aortic stenosis. The right ventricle did not show any change in hemodynamic parameters or in size. These results indicate that aortic stenosis affected the left ventricle only. Consistent with the hemodynamic changes, biochemical changes were also present mainly in the left ventricle. Our previous study ${ }^{5}$ ) also indicated that the right ventricle was not in failure even after 6-9 months of aortic stenosis. Hemodynamic evaluation suggested that 3 months of aortic banding did not produce myocardial failure. The heart rate, cardiac index, $(\mathrm{dP} / \mathrm{dt}) / \mathrm{IIP}$ of ventricular pressures, total systemic vascular resistance, and left ventricular work index did not change significantly after 3 months of aortic stenosis. The left ventricular enddiastolic pressure, however, increased significantly indicating the beginning of failure. These results are consistent with the previous findings of Prasad et al.5)

Plasma sodium, left and right ventricular intracellular potassium and left ventricular tissue calcium decreased significantly after 3 months of aortic stenosis. Intracellular calcium tended to decrease. These findings are consistent with previous findings of Prasad et al. ${ }^{5}$ The tendency of intracellular calcium to decrease might suggest that a change in calcium distribution may be the first pathological change in heart failure. Although there was a tendency for an increase in the sarcolemmal ATPase, this was not significant. Similar findings were observed earlier by Prasad et al. ${ }^{5}$ )

After 3 months of aortic stenosis there was a tendency towards an increase in sarcolemmal ATPase concomitant with a tendency towards a decrease in intracellular calcium and an increase in left ventricular end-diastolic pressure. Concomitant with a tendency towards a decrease in sarcolemmal ATPase, there was a tendency towards a decrease in the intracellular potassium which is consistent with the theory that sarcolemmal ATPase is involved in the regulation of intracellular electrolytes. ${ }^{1 \prime}$

Prazosin treatment for 3 months markedly reduced the cardiac index and left ventricular end-diastolic pressure. The decrease in cardiac index with prazosin treatment might have been due to a significant decrease in left ven- 
tricular end-diastolic pressure and no reduction in systemic vascular resistance. The vasodilator, nitroprusside, has been reported not to improve the cardiac index in patients with aortic stenosis. ${ }^{8}$ Since there were no significant changes in any of the other hemodynamic parameters, it would indicate that prazosin may be having some beneficial effects. In the absence of prazosin, the myocardium would have deteriorated more. In fact in our previous study, ${ }^{5} 6$ to 9 months of aortic stenosis produced a significant decrease in the left ventricu$\operatorname{lar}(\mathrm{dP} / \mathrm{dt}) / \mathrm{IIP}$ and an increase in the left ventricular end-diastolic pressure. The left ventricular end-diastolic pressure increased 2.5 fold and the left ventricular (dP/dt)/IIP decreased to $25 \%$ of the value in normal dogs. The values for left ventricular ( $\mathrm{dP} / \mathrm{dt}$ )/IIP and end-diastolic pressure after 3 months of prazosin treatment were respectively 0.8 and 1.16 times the values in normal dogs. Cardiac index decreased significantly with prazosin treatment. However stroke volume did not change significantly.

Sustained effectiveness of chronic prazosin therapy in severe chronic congestive heart failure has been reported by many investigators. ${ }^{11), 13), 14), 251,26 \text { ) }}$ They all observed a decrease in left ventricular end-diastolic pressure, total systemic vascular resistance, and blood pressure and an increase in cardiac index. The heart rate either remained unchanged or decreased slightly. However, there have been some investigators ${ }^{27)-30)}$ who observed attenuation of the hemodynamic effects of oral prazosin therapy in chronic congestive heart failure.

In the present study there was no improvement in cardiac output and the total systemic vascular resistance increased progressively. There was also no decrease in blood pressure. These findings appear to suggest that there was a tolerance to prazosin. However, the left-ventricular end-diastolic pressure decreased while $(\mathrm{dP} / \mathrm{dt}) / \mathrm{IIP}$ did not decrease suggesting a beneficial effect of prazosin.

Prazosin treatment did not affect plasma and tissue electrolytes. Sarcolemmal $\mathrm{Na}^{+}-\mathrm{K}^{+}-\mathrm{ATPase}$ activity showed a significant decrease in both the left and right ventricles and although the changes were not significant, intracellular calcium did tend to increase. Therefore, prazosin may act to reverse the increased activity of sarcolemmal $\mathrm{Na}^{+}-\mathrm{K}^{+}-\mathrm{ATPase}$ observed in aortic stenosis and return the intracellular calcium concentrations back towards normal levels. It is important to note that in our earlier studies, sarcolemmal $\mathrm{Na}^{+}-\mathrm{K}^{+}-\mathrm{AT}$ Pase increased significantly after 6 to 9 months of aortic stenosis without any treatment. ${ }^{51}$ At present there is no explanation for the tendency towards an increase in $\mathrm{Mg}^{++}$-ATPase after 3 months of aortic stenosis and a significant decrease in this enzyme with prazosin treatment. 


\section{Agknowledgments}

This work was supported by a grant from the Saskatchewan Heart Foundation and forms part of a thesis presented to the University of Saskatchewan by Cathy L. O'Neil in partial fulfillment of the requirements for the M.Sc. degree. During this part of the work Cathy O'Neil was a recipient of a Studentship from the Canadian Heart Foundation.

\section{REFERENGES}

1. Prasad K: Membrane $\mathrm{Na}^{+}-\mathrm{K}^{+}-\mathrm{ATP}$ ase and electromechanics of hurnan heart. in Recent Advances in Studies in Cardiac Structure and Metabolism, Vol 4, Myocardial Biology, ed Dhalla NS, University Park Press, Baltimore, p 91-105, 1974

2. Langer GA, Frank JS, Brady AJ: The myocardium. in International Review of Physiology, Vol 9, Cardiovascular Physiology II, ed by Guyton AC, Cowley AW Jr, University Park Press, Baltimore, p 191-237, 1976

3. Prasad K, Khatter JC, Bharadwaj B: Cardiovascular function in experimental mitral insufficiency in dogs. Jpn Heart J 18: 823, 1977

4. Khatter JC, Prasad K: Myocardial sarcolemmal ATPase in dogs with induced mitral insufficiency. Cardiovase Res 10:637, 1976

5. Prasad K, Khatter JC, Bharadwaj B: Intra- and extracellular electrolytes and sarcolemmal $\Lambda T$ Pase in the failing heart due to pressure overload in dogs. Cardiovasc Res 13: 95, 1979

6. Khatter JC, Singal PK, Bharadwaj B, Prasad K: Cardiac intracellular and blood electrolytes in chronic mitral insufficiency. J Physiol (Paris) 74: 535, 1978

7. Awan NA, Miller RR, DeMaria AN, Amsterdam EA, Mason DT: Vasodilator therapy in valvular aortic stenosis. Improved cardiac performance, reduced left ventricular pressure overload and preservation of coronary blood flow. Circulation 56 (Suppl III): 38, 1977

8. Awan NA, DeMaria AN, Miller RR, Amsterdam EA, Mason DT: Beneficial effects of nitroprusside administration on left ventricular dysfunction and myocardial ischemia in severe aortic stenosis. Am Heart J 101: 386, 1981

9. Mason DT: Symposium on vasodilator and inotropic therapy of heart failure. Am J Med 65: 101, 1978

10. Mehta J, Iacona M, Pepine CJ, Conti R: Comparative hemodynamic effects of nitroprusside, prazosin and hydralazine in refractory heart failure. Am J Cardiol $41: 418,1978$

11. Miller RR, Awan NA, Maxwell KS, Mason DT: Sustained reduction of cardiac impedance and preload in congestive heart failure with the antihypertensive vasodilator prazosin. New Engl J Med 297: 303, 1977

12. Awan NA, Miller RR, Mason DT: Comparison of effects of nitroprusside and prazosin on left ventricular function and the peripheral circulation in chronic refractory congestive heart failure. Circulation 57: 152, 1978

13. Goldman SA, Johnson LL, Escala E, Cannon PJ, Weiss MB: Improved exercise ejection fraction with long term prazosin therapy in patients with heart failure. Am J Med 68: 36, 1980

14. Bertel O, Burkart F, Buhler FR: Sustained effectiveness of chronic prazosin therapy in severe chronic congestive heart failure. Am Heart J 101 : 529, 1981

15. Feldman RG, Ball RM, Winchester MA, Jaillon P, Kates R, Harrison DC: Beneficial hemodynamic response to chronic prazosin therapy in congestive heart failure. Am Heart J $101: 534,1981$

16. Siegel JH, Sonnenblick EH, Judge RD, Wilson WS: The quantification of myocardial contractility in dog and man. Cardiologia 45: 189, 1964

17. Yang SS, Bentivoglio LG, Maranhao V, Goldberg H: From Cardiac Catheterization Data to Haemodynamic Parameters, FA Davis Company, Philadelphia, p 157, 1972 
18. Perkin-Elmer: Analytical methods of atomic absorption spectrophotometry. Standard conditions for calcium. Perkin-Elmar Cor, Edit, Norwalk, Conn, 1971

19. Kidwai AM, Radcliffe MA, Duchon G, Daniel EE: Isolation of plasma membrane from cardiac muscle. Biochem Biophys Res Commun 45: 901, 1971

20. Lowry $\mathrm{OH}$, Roseborough WJ, Farr AL, Randall RJ: Protein measurements with pholin phenol reagent. J Biol Chem 193: 265, 1951

21. Prasad K: Glucagon-induced changes in the action potential, contraction, and $\mathrm{Na}^{+}-\mathrm{K}^{+}-$ ATPase of cardiac muscle. Cardiovasc Res 9: 355, 1975

22. Khatter JC, Prasad K: Frequency-dependent changes in the cardiac sarcolemmal ATPase. Br J Pharmacol 59: 237, 1977

23. Massingham R, Hayden ML: A comparison of the effects of prazosin and hydralazine on blood pressure, heart rate and plasma renin activity in conscious renal hypertensive dogs. Europ J Pharmacol 30: 121, 1975

24. Cavero I: Cardiovascular effects of prazosin in dogs. Clin Sci Molec Med 51 : 609S, 1976

25. Awan NA, Miller RR, DeMaria AN, Maxwell BS, Neumann A, Mason DT: Efficacy of ambulatory systemic vasodilator therapy with oral prazosin in chronic refractory heart failure. Concomitant relief of pulmonary congestive and elevation of pump output demonstrated by improvements in symptomatology, exercise tolerance, haemodynamics and echocardiography. Circulation 56: 346, 1977

26. Aronow WS, Lurie M, Turbow M, Whittaker K, Camp SV, Hughes D: Effect of prazosin vs. placebo on chronic left ventricular heart failure. Circulation 59: 344, 1979

27. Elkayam U, Lejemtel TH, Mathur M, Ribner HS, Frishman WH, Strom J, Sonnenblick EH: Marked early attenuation of haemodynamic effects of oral prazosin therapy in chronic congestive heart failure. Am J Cardiol 44: 540, 1979

28. Packer M, Meller J, Gorlin R, Herman MV: Haemodynamic and clinical tachyphylaxis to prazosin-mediated afterload reduction in severe chronic congestive heart failure. Circulation 59: 531,1979

29. Awan NA, Miller RR, Maxwell KS, Mason DT: Development of systemic vasodilator tolerance to prazosin with chronic use of the agent in ambulatory therapy of severe congestive heart failure. Am J Cardiol 41:367, 1978

30. Harper R, Claxton H, Middlebrook K, Anderson S, Pitt A: Acute and chronic effects of prazosin in severe congestive heart failure. Circulation 59, 60 (Suppl II): 129, 1979 